\title{
ANALISIS KEMAMPUAN PEMECAHAN MASALAH MATEMATIS SEBAGAI DAMPAK PEMBELAJARAN SINEKTIK DAN TIPE KEPRIBADIAN
}

\author{
Chairul Saleh, Hasan Sastra Negara, dan Istihana \\ UIN Raden Intan Lampung \\ e-mail: chairuls1312@gmail.com
}

\begin{abstract}
Abstrak
Tujuan dari penelitian ini adalah (1) mendeskripsikan pengaruh kemampuan pemecahan masalah matematis antara pembelajaran Sinektik dengan peserta didik yang memperoleh pembelajaran konvensional, (2) mendeskripsikan pengaruh tipe kepribadian peserta didik terhadap kemampuan pemecahan masalah matematis peserta didik, dan (3) mendeskripsikan interaksi antara pembelajaran Sinektik terhadap kemampuan pemecahan masalah matematis ditinjau dari tipe kepribadian peserta didik. Jenis penelitian yang digunakan yaitu quasi eksperimental. Desain penelitian posttest only control design dan kelompok dipilih secara random. Hasil penelitian menunjukkan bahwa terdapat pengaruh pembelajaran Sinektik secara signifikan terhadap kemampuan pemecahan masalah matematis, tidak terdapat pengaruh tipe kepribadian terhadap kemampuan pemecahan masalah matematis secara signifikan, dan terdapat interaksi antara pembelajaran Sinektik dan Tipe Kepribadian terhadap kemampuan pemecahan masalah matematis.
\end{abstract}

Kata kunci: Pemecahan Masalah Matematis, Pembelajaran Sinetik, Tipe Kepribadian

\section{ABSTRACT}

This study aims to (1) describe the effect of mathematical problem solving ability between Synectic learning and the students who are going through conventional learning, (2) describe the effect of students 'personality types on students' mathematical problem solving abilities, and (3) describe the interactions between Synectic learning towards mathematical problem solving abilities in terms of the students' personality types. The type of research used is quasi experimental with posttest only control design in which the students were randomly selected. The results showed that there was a significant effect of Synectic learning on students' mathematical problem solving abilities. Besides, there was no significant influence of personality types on students' mathematical problem solving abilities, and there was an interaction between synectic learning and personality types on mathematical problem solving abilities of the students.

Keywords: Problem Solving Mathematically, Synpoietic Learning, Personality Type

\section{PENDAHULUAN}

Pembelajaran matematika diharapkan dapat memeliki kemampuan pemecahan masalah yang baik dalam mengerjakan soal-soal matematika (Fauziah, 2010 dan Hakim, 2015). Kemampuan pemecahan masalah sebagai prasyarat bagi manusia untuk melangsungkan kehidupannya (Wijayanto \& Santoso, 2018), karena diperlukan penguasaan matematika dan menciptakan teknologi dimasa mendatang (Widyawati, 2016 dan Juniati, 
2017). Proses pembelajaran matematika yang monoton dan kurang kreatif, kadang membuat peserta didik sangat jenuh dan sangat bosan (Suzana, Supandi, \& Rahmawati, 2019). Hal ini menyebabkan peserta didik belajar dalam keadaan mengantuk dan tidak konsentrasi (Rahmah \& Hia, 2014 \& Lestari 2015) yang mengakibatkan materi yang diajarkan tidak bisa diserap dengan baik oleh peserta didik (Nosa \& Farida, 2018 dan Maria \& Basri, 2014).

Mengingat setiap peserta didik mempunyai taraf berpikir yang berbeda dan adanya kesulitan peserta didik dalam memecahkan masalah (Putra, 2017), maka keterampilan dan keahlian yang dimiliki seorang pendidik diharapkan mampu memilih pembelajaran yang tepat agar peserta didik menguasai pembelajaran sesuai dengan target yang akan dicapai dalam kurikulum pembelajaran (Rosarina, Sudin, \& Sujana, 2016). Kelebihan pembelajaran Sinektik (Alentina, Putra, \& Negara, 2013 dan Nugraha, 2017) yaitu sebagai (1) mengembangkan pengertian baru pada diri peserta didik tentang suatu masalah sehingga dia sadar bagaimana bertingkah laku dalam situasi tertentu, (2) mengembangkan kejelasan pengertian dan internalisasi pada diri peserta didik tentang materi baru, dan (3) mengembangkan berpikir kreatif, baik pada diri peserta didik maupun guru.

Beberapa penelitian mengenai model pebelajaran Sinektik yang telah dilakukan dan dapat dijadikan kajian dalam penelitian Zannah (2014); Sari, Fitriani, \& Emafetery (2019); dan Damayanti, Purwanti, \& Lestari (2017). Berbagai penelitian mengenai pembelajaran sinetik telah diteliti karena model ini berdampak pisitif dalam pembelajaran, yaitu dapat meningkatkan kemampuan pemecahan masalah (Setiawan 2012; Hamdi, Jamal, \& Annur 2014; Prihartini \& Mediatati, 2013; dan Astuti 2016) kemampuan komunikasi matematis siswa (Permata, Kartono, \& Sunarmi, 2015) pemahaman konsep (Sutrisno, et al., 2015) dan berbagai kemampuan matematis lain dalam pembelajaran (Sari, Fitriani, \& Emafetery, 2019; Nur, et al., 2018; Sukmayati, 2016; Indriani, 2018; Minarni, 2016; Kartika, 2018; Maulani, Suyono, \& Noornia, 2017; Komala, 2012; Mahmud \& Hartono, 2014; Supriadi, 2015; dan Adesty, Nurhanurawati, \& Widyastuti, 2014). Penelitian mengenai hubungan kemampuan pemecahan masalahpun telah banyak dilakukan oleh peneliti sebelumnya ( $\mathrm{Li}$, et al., 2018; Bregant, 2013; Gunur, Alberta, \& Apolonia, 2018; dan Irawan \& Kencanawaty, 2017).

Berdasarkan dari penelitan terdahulu, dirasa menarik untuk dilakuakan penelitian dengan keterbaruan yaitu melihat kemampuan pemecahan masalah menggunakan Pembelajaran sinetik karena penelitian terdahulu belum ada yang meneliti tentang kemampuan pemecahan masalah dengan menerapkan pembelajaran sinetik dan tipe kepribadian. Maka penelitian ini ditujukan untuk (1) menganalisis pengaruh kemampuan pemecahan masalah matematis antara pembelajaran Sinektik dengan peserta didik yang memperoleh pembelajaran konvensional, (2) menganalisis pengaruh tipe kepribadian peserta didik terhadap kemampuan pemecahan masalah matematis peserta didik, dan (3) 
menganalisis interaksi antara pembelajaran Sinektik terhadap kemampuan pemecahan masalah matematis ditinjau dari tipe kepribadian peserta didik. Jenis penelitian yang digunakan yaitu quasi eksperimental design.

\section{METODE PENELITIAN}

Jenis penelitian yang digunakan yaitu quasi eksperimental. Desain penelitian yang digunakan pada penelitian ini adalah posttest only control design. Pada design ini terdapat dua kelompok yang masing-masing dipilih secara random. Rancangan penelitian yang digunakan dalam penelitian ini dengan maksud untuk mengetahui pengaruh variabel bebas terhadap variabel terkait. Rancangan penelitian yang digunakan dalam penelitian ini seperti Tabel 1.

Tabel 1 Rancangan Penelitian

\begin{tabular}{lcccc}
\hline $\begin{array}{c}\text { Hyuyjumbjmmn mn } \\
\text { Tipe kepribadian } \\
\left(B_{j}\right)\end{array}$ & $\begin{array}{c}\text { Sanguinis } \\
\left(B_{1}\right)\end{array}$ & $\left(B_{2}\right)$ & $\left(B_{3}\right)$ & $\begin{array}{c}\text { Melancholis } \\
\text { Model }\end{array}$ \\
$\begin{array}{l}\text { Pembelajaran }\left(A_{\boldsymbol{i}}\right) \\
\text { Pembelajaran Sinektik }\left(A_{1}\right)\end{array}$ & $A_{1} B_{1}$ & $A_{1} B_{2}$ & $A_{1} B_{3}$ & $A_{1} B_{4}$ \\
Pembelajaran Konvensional $\left(A_{2}\right)$ & $A_{2} B_{1}$ & $A_{2} B_{2}$ & $A_{2} B_{3}$ & $A_{2} B_{4}$ \\
\hline
\end{tabular}

Penelitian dilaksanakan di SMP Negeri 3 Terbanggi Besar, Kabupaten Lampung Tengah. Tes yang dilakukan berupa soal uraian (essay). Tes uraian yang diujikan terdiri dari 5 item soal. Data kepribadian diperoleh menggunakan angket peserta didik. Teknik analisis data yang digunakan menguji hipotesisi penelitian adalah uji t dua sampel tidak berkorelasi, sebelum melakukan uji hipotesis, dilakukan uji prasyarat yaitu uji normalitas dan uji homogenitas.

\section{HASIL DAN PEMBAHASAN}

Data dikumpulkan setelah pembelajaran selesai, diujikan tes kemampuan pemecahan masalah matematis pada peserta didik. Setelah tes kemampuan pemecahan masalah matematis, selanjutnya dikumpulkan data nilai kelas eksperimen dan kelas kontrol, maka diperoleh pada Tabel 2.

Tabel 2. Data Hasil Tes Kemampuan Pemecahan Masalah

\begin{tabular}{cccccc}
\hline \multirow{2}{*}{ Kelompok } & \multirow{2}{*}{$\boldsymbol{X}_{\text {max }}$} & $\boldsymbol{X}_{\boldsymbol{m i n}}$ & \multicolumn{3}{c}{ Ukuran Tendensi Sentral } \\
& & & $\overline{\boldsymbol{x}}$ & $\boldsymbol{M}_{\boldsymbol{o}}$ & $\boldsymbol{M}_{\boldsymbol{e}}$ \\
\hline Eksperimen & 96 & 16 & 59,355 & 80 & 74 \\
Kontrol & 80 & 24 & 46,839 & 46 & 46 \\
\hline
\end{tabular}


Data angket tipe kepribadian dibagikan kepada peserta didik baik kelas eksperimen maupun kelas kontrol, selanjutnya data angket dikumpulkan kembali, untuk melihat tipe kepribadian dari masing-masing peserta didik terlihat pada Tabel 3.

Tabel 3. Data Hasil Angket Tipe Kepribadian

\begin{tabular}{lcccc}
\hline \multicolumn{1}{c}{ Kelas } & \multicolumn{4}{c}{ Tipe Kepribadian } \\
& Koleris & Melankolis & Plegmatis & Sanguinis \\
\hline Eksperimen & 8 & 4 & 10 & 9 \\
Kontrol & 3 & 5 & 15 & 8 \\
\hline
\end{tabular}

Uji normalitas menggunakan uji lilifors dengan taraf signifikansi 0,05 . Hasil uji normalitas kelompok data tersebut disajikan pada Tabel 4.

Tabel 4. Hasil Uji Normalitas Data Kemampuan Pemecahan Masalah Matematis dan Data Tipe Kepribadian

\begin{tabular}{lccl}
\hline \multicolumn{1}{c}{ Kelas } & $\boldsymbol{L}_{\text {Hitung }}$ & $\boldsymbol{L}_{\text {Tabel }}$ & \multicolumn{1}{c}{ Keputusan Uji } \\
\hline Eksperimen $\left(a_{1}\right)$ & 0,152 & 0,156 & Berdistribusi Normal \\
Kontrol $\left(a_{2}\right)$ & 0,140 & 0,156 & Berdistribusi Normal \\
Koleris $\left(b_{1}\right)$ & 0,223 & 0,250 & Berdistribusi Normal \\
Melankolis $\left(b_{2}\right)$ & 0,240 & 0,274 & Berdistribusi Normal \\
Plegmatis $\left(b_{3}\right)$ & 0,153 & 0,172 & Berdistribusi Normal \\
Sanguinis $\left(b_{4}\right)$ & 0,197 & 0,207 & Berdistribusi Normal \\
\hline
\end{tabular}

Berdasarkan hasil uji normalitas data peserta didik yang terangkum dalam Tabel , tampak bahwa taraf signifikansi $5 \%$ nilai $\mathrm{L}_{\text {maks }}$ untuk setiap kelompok kurang dari $\mathrm{L}_{0,05 ; n}$, sehing ga hipotesis nol untuk setiap kelompok diterima. Sehingga dapat disimpulkan bahwa data pada setiap kelompok berasal dari populasi yang berdistribusi normal. Uji varians data penelitian ini menggunakan uji Bartlett. Perhitungan Hasil uji homogenitas Posttest dengan taraf signifikansi $(\alpha)=5 \%$ telah tercantum pada rangkuman Tabel 5 .

Tabel 5. Uji Homogenitas Posttest

\begin{tabular}{cccc}
\hline Kelompok & $\boldsymbol{L}_{\text {hitung }}$ & $\boldsymbol{L}_{\text {tabel }}$ & Keputusan Uji \\
\hline$a_{1}$ dan $a_{2}$ & 2,25 & 3,84 & $\mathrm{H}_{0}$ diterima \\
$b_{1}, b_{2}, b_{3}$, dan $b_{4}$ & 2,788 & 7,815 & $\mathrm{H}_{0}$ diterima \\
\hline
\end{tabular}

Berdasarkan Tabel tampak bahwa harga kelompok tidak melebihi harga kritiknya. Dari data hasil perhitungan antar kelas esperimen dan kelas kontrol diperoleh $L_{\text {hitung }}=2,25$ dengan $L_{\text {tabel }}=3,84$ sehingga $\mathrm{H}_{0}$ diterima dan data hasil perhitungan antar tipe kepribadian $L_{\text {hitung }}=2,788$ dengan $L_{\text {tabel }}=7,815$. Dengan demikian dapat diambil kesimpulan bahwa sampel berasal dari populasi yang homogen. Berikut ini adalah rangkuman hasil perhitungan uji analisis variansi dua jalan: 
Tabel 6. Hasil Analisis Varians Dua Jalan

\begin{tabular}{|c|c|c|c|c|c|c|}
\hline \multirow[b]{2}{*}{ SK } & \multicolumn{4}{|c|}{ Tabel Anava Dua Arah } & \multirow[b]{2}{*}{$F_{\text {tabel }}$} & \multirow[b]{2}{*}{ Simpulan } \\
\hline & JK & Dk & RK & $F_{\text {hitung }}$ & & \\
\hline $\begin{array}{l}\text { Model } \\
\text { Tipe }\end{array}$ & $5,504.333$ & 1 & 5504.333 & 11.381 & 4.03 & Ho Ditolak \\
\hline Kepribadian & 113.806 & 3 & 37.935 & 0.078 & 2.79 & Ho Diterima \\
\hline Interaksi & 8152.662 & 3 & 2717.554 & 5.619 & 2.79 & Ho Ditolak \\
\hline Galat & 2717.554 & 54 & 483.633 & & & \\
\hline Total & $16,488.355$ & 61 & & & & \\
\hline
\end{tabular}

Hasil anava dua jalan sel tak sama disimpulkan bahwa (1) $F_{a}=11.381$ dengan taraf signifikasi 0,05 diperoleh $F_{(0,05 ; 1 ; 54)}=4,03$ sehingga $F_{a}>F_{(0,05 ; 1 ; 54)}$ yang menunjukan bahwa $H_{0 A}$ ditolak yang berarti terdapat pengaruh pembelajaran Sinektik terhadap kemampuan pemecahan masalah matematis; (2) $F_{b}=0.078$ dengan taraf signifikasi 0,05 diperoleh $F_{(0,05 ; 3 ; 54)}=2,79$ sehingga $F_{b}<F_{(0,05 ; 3 ; 54)}$ yang menunjukan bahwa $H_{O B}$ diterima yang berarti tidak terdapat pengaruh tipe kepribadian (Sanguinis, Koleris, Melankolis, dan Plegmatis) terhadap kemampuan pemecahan masalah matematis; dan (3) $F_{a b}=5.619$ dengan taraf signifikasi 0,05 diperoleh $F_{(0,05 ; 3 ; 54)}=2,79$ sehingga $F_{b}<F_{(0,05 ; 3 ; 54)}$ yang menunjukan bahwa $H_{0 A B}$ ditolak yang berarti terdapat interaksi antara model pembelajaran Sinektik dan Tipe Kepribadian terhadap kemampuan pemecahan masalah matematis.

Berdasarkan hasil analisis statistik data didapatkan hasil yang sangat signifikan antara $F_{\text {hitung }}$ dan $F_{\text {tabel }}$. Hasil dari perhitugan analisis statistic tersebut adalah bahwa terdapat pergaruh model pembelajaran Sinektik dan pembelajaran Konvensional terhadap kemampuan pemecahan masalag matematis pada materi Sistem Persamaan Lenear Dua Variabel (SPLDV). Hasil perhitungan komparansi ganda dengan metode scheffe' adalah terdapat perbedaan yang sangat signifikan antara model pemebelajaran Sinektik dibadingkan dengan pembelajaran Konvensional terhadap kemampuan pemecahan masalah matematis peserta didik. Menurut Gordon (1961) pada model pembelajaran Sinektik menempatkan tim dalam kooperasi antara satu dengan yang lainnya untuk mempelajari sebuah topik dalam kelas yang lebih diutamakan ialah kreativitas peserta didik dengan kelompok maupun dengan antar kelompok, dimana menurut Mulyono (2018) bahwa kreativitas peserta didik sangat penting dan menunjang efektivitas pembelajaran.

Pada pertemuan kelima kelas eksperimen serta kontrol dilakukan evaluasi tes kemampuan pemecahan masalah matematis. Evaluasi pada kelas eksperimen mendapatkan rata-rata 59,355 dan pada kelas kontrol mendapatkan rata-rata 46,839. Hasil tersebut menunjukan rata-rata nilai yang didapatkan kelas eksperimen lebih tinggi dari ratarata nilai yang didapatkan kelas kontrol. Hasil angket Tipe Kepribadian kelas eksperimen pada kriteria Koleris, Melankolis, Plegmatis, dan Sanguinis diperoleh dari 31 peserta didik 
terpilih 8 peserta didik dengan kecerdasan Koleris, 4 peserta didik dengan kecerdasan Melankolis, 10 peserta didik dengan kecerdasan Plegmatis, dan 9 peserta didik dengan kecerdasan Sanguinis. Pada kelas kontrol dari 31 peserta didik terdapat 3 peserta didik memiliki kecerdasan Koleris, 5 peserta didik memiliki kecerdasan Melankolis, 15 peserta didik memiliki kecerdasan Plegmatis, dan 8 peserta didik memiliki kecerdasan Sanguinis. Setelah mendapatkan hasil tes kemampuan pemecahan masalah matematis, maka dilakukan uji normalitas dengan uji Lillifors yang memperlihatkan sampel berdistribusi normal, dilanjutkan uji Bartlett yang menunjukan kedua kelas mempunyai variansi yang homogen, kemudian diteruskan uji hipotesis dengan uji parametrik yakni uji anava.

Perhitungan dengan anava dua jalan sel tak sama menghasilkan hipotesis yang pertama yaitu terdapat pengaruh antara model Sinektik terhadap kemampuan pemecahan masalah matematis, hal tersebut ditunjukan oleh $F_{\text {hitung }}>F_{\text {tabel }}$ yang artinya $\mathrm{H}_{0}$ ditolak. Setelah uji anava, dilakukan uji komparasi ganda lalu diperoleh rataan yang mendapatkan perlakuan dengan model Sinektik lebih baik dari perlakuan dengan menggunakan metode konvensional. Oleh sebab itu disimpulkan bahwa kemampuan pemecahan masalah matematis yang diberikan menggunakan model Sinektik lebih baik dari yang diajarkan dengan metode konvensional.

Kegiatan pembelajaran yang dilaksanakan di SMP Negeri 3 Terbanggi Besar menggunakan model Sinektik, peserta didik terlihat lebih antusias dalam melaksanakan proses pembelajaran di kelas. Pada saat proses belajar mengajar berjalan peserta didik tampak lebih bersemangat serta aktif dalam mengikuti pelajaran, peserta didik bisa mengulang dan mengingat kembali materi SPLDV yang disampaikan dengan beberapa gesture yang diberikan oleh guru, peserta didik dapat bertukar pikiran dengan pasangan sebangkunya hingga saling bertukar pendapat agar memperoleh kesimpulan dari materi yang diberikan. Selama proses pelaksanaan pembelajaran pada langkah "Deskripsi Kondisi" guru meminta peserta didik untuk mencari hubungan antara SPLDV dengan kehidupan sehari-hari, selanjutnya pada langkah "Analogi Langsung (Elaborasi)" Peserta didik yang tidak mengerti dianjurkan untuk bertanya kepada peserta didik lain yang sudah mengerti. Kegiatan ini dapat membuat peserta didik saling berinteraksi satu sama lain seperti memaparkan kembali materi yang sudah diberikandari pendidik serta dapat menyelesaikan soal yang diberikan pendidik sesuai tahap-tahapanya, karena umumnya kemampuan pemecahan masalah matematis pada proses pembelajaran dapat membantu peserta didik untuk menyimpulkan, merencanakan penyelesaian, dan menyelesaikan masalah yang ada pada matematika.

Metode Konvensional merupakan pembelajaran tradisional serupa seperti ceramah, sebab metode tersebut dipakai pada kegiatan pembelajaran di SMP Negeri 3 Terbanggi Besar. Pelaksanaan diskusi serta pemberian soal hanya diberikan pada materi tertentu. 
Peserta didik dalam kelas kontrol menggunakan metode konvensional tampak kurang antusias dalam kegiatan pembelajaran. Hal ini tampak pada proses pembelajaran yang akan dimulai peserta didik banyak yang mengobrol serta belum mempersiapkan buku pelajaran matematika. Saat proses belajar mengajar berjalan peserta didik tampak membisu dan tidak bersemangat untuk kegiatan pembelajaran disebabkan mereka hanya mendengar, menyimak dan mencatat materi yang disampaikan.

Semestinya peserta didik yang diberikan model Sinektik dapat menghasilkan kemampuan pemecahan masalah matematis yang lebih baik dari pada peserta didik yang diajarkan dengan metode konvensional. Hasil penelitian menunjukan kemampuan pemecahan masalah matematis peserta didik yang menggunakan model Sinektik lebih baik dari pada peserta didik yang mendapatkan pembelajaran konvensional.

Hal tersebut dipertegas melalui beberapa relevansi penelitian yang dilakukan yakni, penelitian yang dilakukan oleh Zannah (2014), yaitu hasil penelitian setelah dilakukannya pada siklus 1 pada per test $0 \%$ menjadi 13,63\% pada post tes, pada siklus ke 2 hasil pre test $39,13 \%$ menjadi $91,30 \%$ pada post test dan pada siklus 3 hasil pre test, $28,57 \%$ menjadi $57,14 \%$ pada post test. Hasil belajar dari siklus 1 ke siklus 2 mengalami peningkatan dan mencapai ketuntasan klasikal namun pada siklus 3 mengalami penurunan, tetapi setelah dilakukan analisis perbutir soal diketahui kalau penurunan tersebut bukan karena soal sinektik. Selanjutnya, penelitian yang dilakukan oleh Agustina, Pasaribu, \& Saehana, (2014), di mana bahwa model pembelajaran yang digunakan memberikan dampak positif terhadap hasil belajar peserta didik. Hal ini dapat dilihat berdasarkan hasil post-test hasil belajar peserta didik skor rata-rata kelas kontrol sebesar 12,07 dengan standar deviasinya adalah 2,04 dan skor rata-rata kelas eksperimen sebesar 15,61 dengan standar deviasinya adalah 2,23 dari skor maksimum 19.

Hipotesis kedua disimpulkan bahwa tidak ada pengaruh antara Tipe Kepribadian (Koleris, Melankolis, Plegmatis, dan Sanguinis) terhadap kemampuan pemecahan masalah matematis. Sinektik yang dimiliki peserta didik terhadap pembelajaran matematika nyatanya tidak ada pengaruh dengan hasil posttest. Hal ini tampak dari hasil posttest kemampuan pemecahan masalah matematis yang sudah diberikan perlakuan pembelajaran.

Hasil perhitungan diperoleh pada analisis variansi dua jalan sel tak sama, didapatkan $F_{\text {hitung }}<F_{\text {tabel }}$ yang menunjukkan bahwa $\mathrm{H}_{0}$ diterima, yang berarti tidak terdapat ada pengaruh kemampuan pemecahan masalah matematis peserta didik yang memiliki Tipe Kepribadian (Koleris, Melankolis, Plegmatis, dan Sanguinis). Hal ini menunjukan bahwa tidak ada perbedaan antara peserta didik yang memiliki Tipe Kepribadian (Koleris, Melankolis, Plegmatis, dan Sanguinis) pada pembelajaran yang menggunakan model Sinektik dan peserta didik dengan metode konvensional. 
Uji pasca anava melihat antara marginaldi tidak ada perbedaan yang signifikan antara peserta didik yang mempunyai kecerdasan Koleris dan kecerdasan Melankolis, tidak ada perbedaan yang relevan antara peserta didik yang memiliki kecerdasan Koleris dan kecerdasan Plegmatis, tidak ada perbedaan yang relevan antara peserta didik yang memiliki Koleris dan kecerdasan kecerdasan Sanguinis, tidak ada perbedaan yang relevan antara peserta didik yang mempunyai Melankolis dan kecerdasan kecerdasan Plegmatis, tidak ada perbedaan yang relevan antara peserta didik yang memiliki Melankolis dan kecerdasan kecerdasan Sanguinis, serta tidak ada perbedaan yang relevan antara peserta didik yang mempunyai Plegmatis dan kecerdasan kecerdasan Sanguinis.

Secara teori menyatakan bahwa yang dapat mempengaruhi kemampuan pemecahan masalah matematis merupakan Tipe Kepribadian serta pemakaian model pembelajaran yang tepat oleh pendidik (Amalia \& Widodo,2018; Fatmawati, Indah, \& Khabibah, 2019; dan Sunarto, Budayasa, \& Juniati, 2017). Hal ini juga seperti pada penelitian sebelumnya, yaitu penelitian yang dilakukan oleh Oktaviana, D., \& Susiaty, U. D. (2017), yaitu berdasarkan hasil analisis data dan pembahasan yang telah diuraikan maka terdapat pengaruh Tipe Kepribadian Peserta didik terhadap prestasi belajar matematika peserta didik. Berarti peserta didik dengan tipe kepribadian Sanguinis, Melankolis, Koleris , dan Plegmatis memiliki prestasi belajar matematika yang sama. Dibuktikan dari hasil analisis diperoleh $f_{\text {hitung }}=0,139<f_{\text {tabel }}=2,92$. Akan tetapi pada penelitian ini tidak ada kaitanya antara Tipe Kepribadian terhadap kemampuan pemecahan masalah matematis. Ketidak tepatan hasil penelitian dengan teori dikarenakan saat pengisian angket belum jujur dan adanya kerjasama dalam mengerjakan soal tes kemampuan pemecahan masalah matematis. Hal itu mampu berpengaruh terhadap hasil yang tidak tepat dengan teori yang ada.

Hipotesis ketiga yaitu mengetahui apakah terdapat interaksi antar model pembelajaran dengan tipe kepribadian peserta didik terhadap kemampuan pemecahan masalah matematis. Berdasarkan hasil ANOVA dua jalan sel tak sama diperoleh bahwa hasil $H_{0}$ ditolak, ini berati terdapat interaksi antara model pembelajara Sinektik dan tipe kepribadian terhadap kemampuan pemecahan masalah matematis peserta didik.

Beberapa penelitian mengenai model pebelajaran Sinektik yang telah dilakukan dan dapat dijadikan kajian dalam penelitian yaitu: Penelitian yang dilakukan oleh (Zannah, 2014) menunjukkan bahwa setelah dilakukannya siklus belajar dan post test. Hasil belajar mengalami peningkatan dan mencapai ketuntasan klasikal namun pada siklus 3 mengalami penurunan. Selain itu, Penelitian yang dilakukan (Damayanti, Purwanti, \& Lestari, 2017) menyatakan bahwa penyesuaian diri peserta didik dari masing-masing tipe kepribadian menunjukkan respon-respon terhadap suatu situasi yang sesuai dengan karakteristik kepribadiannya, kemudian sebagian besar penyesuaian diri peserta didik termasuk dalam 
kategori baik. Berdasarkan uraian tersebut, hasil penelitian ini adalah adanya pengaruh model pembelajaran Sinektik terhadap kemampuan pemecahan masalah matematis ditinjau dari tipe kepribadian peserta didik.

\section{SIMPULAN}

Simpulan dalam penelitian ini adalah (1) terdapat pengaruh pembelajaran Sinektik terhadap kemampuan pemecahan masalah matematis peserta didik menggunakan pembelajaran Sinektik lebih baik dibandingkan kemampuan pemecahan masalah matematis menggunakan pembelajaran konvensional; (2) tidak terdapat pengaruh antara peserta didik yang memiliki tipe kepribadian (koleris, melankolis, plegmatis, dan sanguinis) terhadap kemampuan pemecahan masalah matematis peserta didik; dan (3) terdapat interaksi antara model pembelajaran Sinektik dengan tipe kepribadian terhadap kemampuan pemecahan masalah matematis peserta didik. Berdasarkan hasil ini, perlu diperhatikan bahwa dalam pelaksanaan pembelajaran semestinya menggunakan model belajar yang lebih bervariatif sehingga peserta didik dapat antusias mengatasi rasa jenuh. Bagi peneliti selanjutnya agar mampu melihat kemampuan matematis lain yang peserta didik miliki, serta menerapkan model Sinektik pada materi lainnya.

\section{DAFTAR PUSTAKA}

Adesty, M., \& Nurhanurawati, N. 2014. Pengaruh Model Pembelajaran Kooperatif Tipe NHT Terhadap Kemampuan Komunikasi Matematis dan Belief. Jurnal Pendidikan Matematika Unila, 2(2).

Agustina, S., Pasaribu, M., \& Saehana, S. 2014. Pengaruh Model Pembelajaran Sinektik Terhadap Hasil Belajar Fisika pada Siswa Kelas X SMA Negeri 4 Palu. JPFT (Jurnal Pendidikan Fisika Tadulako Online), 4(2), 42-46.

Alentina, N. P., Putra, M., \& Negara, I. G. A. O. 2013. Model Pembelajaran Sinektik Berbasis Penilaian Portofolio Berpengaruh terhadap Hasil Belajar IPS Siswa Kelas V SD Gugus Letkol Wisnu Denpasar Utara. Mimbar PGSD Undiksha, 1(1).

Amalia, S. R., \& Widodo, A. N. A. 2019. Analisis Kemampuan Pemecahan Masalah melalui Model PBL Berbasis Etnomatematika Ditinjau dari Tipe Kepribadian Sanguinis dan Melankholis. In PRISMA, Prosiding Seminar Nasional Matematika (Vol. 2, pp. 156160).

Amalia, S.R., \& Widodo, A.N.A. 2018. Analisis Kemampuan Pemecahan Masalah Mahasiswa Melalui Model Pbl Berbasis Etnomatematika Ditinjau dari Kepribadian Topologi Hippocrates dan Galenus Tipe Cholearis dan Phlegmantis. AKSIOMA: Jurnal Matematika dan Pendidikan Matematika, 9(1), 1-10.

Astuti, A. 2016. Pengaruh Model Pembelajaran Kooperatif Tipe Two Stay Two Stray (TSTS) Terhadap Hasil Belajar Matematika Siswa Kelas Vii Smp Negeri 2 Bangkinang Kota. Jurnal Cendekia: Jurnal Pendidikan Matematika,[SL], (2), 11-28. 
Bregant, T. 2013. Brain Mechanism Underlying Numerical Processing. Psiholoska Obzorja $21(3): 69-74$.

Damayanti, H., Purwanti, P., \& Lestari, S. 2017. Analisis Penyesuaian Diri Ditinjau dari Tipe Kepribadian Peserta Didik Kelas X SMAN 1 Pontianak. Jurnal Pendidikan dan Pembelajaran, 6(11).

Fatmawati B.M, Indah, \& Khabibah, S. 2019. Profil Siswa SMP dalam Memecahkan Masalah Matematika Ditinjau dari Tipe Kepribadian. MATHEdunesa, 8(2).

Fauziah, A. 2010. Peningkatan Kemampuan Pemahaman dan Pemecahan Masalah Matematik Siswa SMP melalui Strategi REACT. In Forum kependidikan (Vol. 30, No. 1, pp. 1-13).

Gordon, W. J. 1961. Synectics: The Development of Creative Capacity.

Gunur, B., Makur, A. P., \& Ramda, A. H. 2018. Hubungan Antara Kemampuan Numerik dengan Kemampuan Pemecahan Masalah Matematis Siswa Di Pedesaan. MaPan, 6(2), 148-160.

Hakim, A. R. 2015. Pengaruh Model Pembelajaran Generatif terhadap Kemampuan Pemecahan Masalah Matematika. Formatif: Jurnal IImiah Pendidikan MIPA, 4(3).

Hamdi, R., Jamal, M. A., \& An'nur, S. 2014. Meningkatkan Hasil Belajar Fisika dengan Menerapkan Model Pembelajaran Kooperatif Tipe Two Stay Two Stray. Berkala IImiah Pendidikan Fisika, 2(3), 265-273.

Hutagaol, K. 2013. Pembelajaran Kontekstual untuk Meningkatkan Kemampuan Representasi Matematis Siswa Sekolah Menengah Pertama. Infinity Journal, 2(1), 85-99.

Indriani, L. F., Yuliani, A., \& Sugandi, A. I. 2018. Analisis Kemampuan Penalaran Matematis dan Habits of Mind Siswa SMP Dalam Materi Segiempat dan Segitiga. Jurnal Math Educator Nusantara: Wahana Publikasi Karya Tulis IImiah Di Bidang Pendidikan Matematika, 4(2), 87-94. doi.org/10.29407/jmen.v4i2.11999.

Irawan, A., \& Kencanawaty, G. 2017. Peranan Kemampuan Verbal dan Kemampuan Numerik terhadap Kemampuan Berpikir Kritis Matematika. AKSIOMA: Jurnal Program Studi Pendidikan Matematika, 5(2), 110-119.

Juniati, E. 2017. Peningkatkan Hasil Belajar Matematika melalui Metode Drill dan Diskusi Kelompok pada Siswa Kelas VI SD. Scholaria: Jurnal Pendidikan dan Kebudayaan, 7(3), 283-291.

Kartika, Y. 2018. Analisis Kemampuan Pemahaman Konsep Matematis Peserta Didik Kelas VII SMP pada Materi Bentuk Aljabar. Jurnal Pendidikan Tambusai 2 (58): 777-85.

Komala, E. 2012. Pembelajaran dengan Pendekatan Diskursif untuk Meningkatkan Kemampuan Pemecahan Masalah Matematis dan Self-Concept Siswa Sekolah Menengah Pertama. Tesis pada SPS UPI. Tidak dipublikasikan.

Lestari, I. 2015. Pengaruh Waktu Belajar dan Minat Belajar Terhadap Hasil Belajar Matematika. Formatif: Jurnal IImiah Pendidikan MIPA 3 (2). 
Li, Y., Zhang, M., Chen, Y., Deng, Z., Zhu, X., \& Yan, S. 2018. Children's Non-Symbolic and Symbolic Numerical Representations and Their Associations with Mathematical ability. Frontiers in psychology, 9, 1035.

Mahmud, D. A., \& Hartono, H. 2014. Keefektifan Model Pembelajaran Isk dan Ditinjau Dari Motivasi, Sikap, dan Kemampuan Komunikasi Matematis. Jurnal Riset Pendidikan Matematika, 1(2), 188-201.

Maria, M., \& Basri, B. 2014. Analisis Kesulitan Belajar Siswa pada Materi Persamaan Dasar Akuntansi Kelas XI IPS di SMA. Jurnal Pendidikan dan Pembelajaran Untan, 3(8).

Maulani, D., Suyono, S., \& Noornia, A. 2017. Pengaruh Penerapan Model Reciprocal Teaching Terhadap Kemampuan Komunikasi Matematis Ditinjau Dari Self-Concept Siswa Di Sman Kecamatan Tambun Selatan Bekasi. JPPM (Jurnal Penelitian dan Pembelajaran Matematika), 10(2).

Minarni, A. 2016. Pengaruh Pembelajaran Berbasis Masalah terhadap Kemampuan Pemecahan Masalah Matematis, no. December.

Mulyono, Y. 2018. Improving Creativity of the Future Physics Teachers Through General Biology Learning Based on CTL with Experimental Method. Indonesian Journal of Science and Education, 2(1), 62-68.

Muslim, S. R. 2017. Pengaruh Penggunaan Model Project Based Learning Terhadap Kemampuan Pemecahan Masalah Matematik Peserta Didik SMA. SJME (Supremum Journal of Mathematics Education), 1(2), 88-95.

Nopitasari, D. 2016. Pengaruh Model Pembelajaran Creative Problem Solving (CPS) Terhadap Kemampuan Penalaran Adaptif Matematis Siswa. Mathline: Jurnal Matematika dan Pendidikan Matematika, 1(2), 103-112.

Nosa, D. E., \& Farida, F. 2018. Aplikasi Wingeom dan Camtasia Studio untuk Pembuatan Media Pembelajaran Audio Visual. Desimal: Jurnal Matematika, 1(2), 127-137.

Nugraha, E. 2017. Model Sinektik Berorientasi Berpikir Kreatif dalam Pembelajaran Menulis Naskah Drama (Kuasi Eksperimen Terhadap Siswa Kelas VIII SMP PGII 2 Bandung). Literasi: Jurnal IImiah Pendidikan Bahasa, Sastra Indonesia dan Daerah 7 (2): 12131.

Nur, F., Latuconsina, N. K., Abrar, A. I. P., Tayeb, T., \& Syamsuarni, I. (2018). Mathematical Learning Outcome Differences Through The Implementation of Cooperative Learning Model of Think Pair Share Type, Two Stay Two Stray Type, and Number Head Together Type. Mapan: Jurnal Matematika dan Pembelajaran, 6(2), 199-206.

Oktaviana, D., \& Susiaty, U. D. 2017. Perbedaan Prestasi Belajar Matematika Ditinjau dari Tipe Kepribadian Siswa dalam Pembelajaran Matematika. SAP (Susunan Artikel Pendidikan), 2(2).

Permata, C. P., Kartono, K., \& Sunarmi, S. 2015. Analisis Kemampuan Komunikasi Matematis Siswa Kelas VIII SMP pada Model Pembelajaran TSTS dengan Pendekatan Scientific. Unnes Journal of Mathematics Education, 4(2).

Prihartini, P., \& Mediatati, N. 2013. Perbedaan Pengaruh Metode Pembelajaran Kooperatif Tipe TSTS (Two Stay Two Stray) dan Metode Ceramah Terhadap Hasil Belajar PKn 
pada Siswa Kelas X SMA Negeri 1 Pabelan Kecamatan Pabelan Kabupaten Semarang Semester Ganjil Tahun Ajaran 2012/2013. Satya Widya, 29(2), 127-133.

Putra, F.G. 2017. Eksperimentasi Pendekatan Kontekstual Berbantuan Hands on Activity (HoA) terhadap Kemampuan Pemecahan Masalah Matematik. Al-Jabar: Jurnal Pendidikan Matematika 8 (1): 73-80.

Rahmah, A., \& Hia, Y. D. 2014. Faktor-Faktor Yang Mempengaruhi Kesulitan Belajar Mata Pelajaran Ekonomi Siswa Kelas XII IPS SMAN 2 Sijunjung. Journal of Economic and Economic Education Vol, 3(1), 71-78.

Rosarina, G., Sudin, A., \& Sujana, A. 2016. Penerapan model discovery learning untuk meningkatkan hasil belajar siswa pada materi perubahan wujud benda. Jurnal Pena Ilmiah, 1(1).

Sari, D. F., Fitriani, S. S., \& Emafetery, S. 2019. The Strategy of Two Stay Two Stray to Improve EFL Students' Reading Skill. Studies in English Language and Education, 6(1), 171-184.

Setiawan, A. T. 2012. Pengaruh Pembelajaran Kooperatif Two Stay Two Stray Berpendekat an SETS Terhadap Hasil Belajar Kimia Siswa SMA Negeri 1 Comal. Jurnal Inovasi Pendidikan Kimia, 6(1).

Sukmayati. 2016. Applying Two Stay Two Stray Strategy To Improve Students Reading Comprehension. GEEJ 1 (1).

Sunarto, M. D., Budayasa, I. K., \& Juniati, D. 2017. Profil Proses Berpikir Mahasiswa Tipe Kepribadian Sensing dalam Pemecahan Masalah Logika Matematika. Cakrawala Pendidikan, (2), 95007.

Supriadi, N. 2015. Pembelajaran Geometri Berbasis Geogebra Sebagai Upaya Meningkatkan Kemampuan Komunikasi Matematis Siswa Madrasah Tsanawiyah (MTs). Al-Jabar: Jurnal Pendidikan Matematika 6 (2): 99-109.

Sutrisno, A. D., Samsudin, A., Liliawati, W., Kaniawati, I., \& Suhendi, E. 2015. Model Pembelajaran Two Stay Two Stray (TSTS) dan Pemahaman Siswa Tentang Konsep Momentum dan Impuls. Jurnal Pengajaran MIPA, 20(1), 38-42.

Suzana, R., Supandi, S., \& Rahmawati, N. D. 2019. Pengaruh Model Pembelajaran Creative Problem Solving Berbantu Mind Mapping pada Pembelajaran Matematika. Senatik, 356-361.

Syazali, M. 2015. Pengaruh Model Pembelajaran Creative Problem Solving Berbantuan Maple II Terhadap Kemampuan Pemecahan Masalah Matematis. Al-Jabar: Jurnal Pendidikan Matematika 6 (1): 91-98. https://doi.org/10.24042/ajpm.v6i1.58.

Tavakoli, H.M. 2016. The Relationship between Accuracy of Numerical Magnitude Coparisons and Children's Arithmetic Ability: A Study in Iranian Primary School Children. Europes Journal of Psychology 12 (4): 567-83.

Wahyuni, I \& Yanty G.M. 2014. Pengaruh Model Pembelajaran Kooperatif Tipe Two Stay Two Stray Terhadap Hasil Belajar Siswa Pada Materi Listrik Dinamis Pada Siswa SMA. Jurnal Pendidikan Fisika 3 (1): 1-7. 
Widyawati, S. 2016. Pengaruh Gaya Belajar Terhadap Prestasi Belajar Mahasiswa Program Studi Pendidikan Matematika (IAIM NU) Metro. Al-Jabar: Jurnal Pendidikan Matematika 7 (1): 107-14.

Wijayanto, R., \& Santoso, R. H. 2018. Pengembangan Bahan Ajar Matematika dengan Pendekatan Problem Solving Berorientasi pada Kemampuan Pemecahan Masalah. Jurnal Pendidikan Matematika-S1, 7(3), 95-104.

Zannah, F. 2014. Penggunaan Model Sinektik Untuk Meningkatkan Pemahaman Konsep Sistem Peredaran Darah Manusia Pada Siswa Kelas XI SMAN. Edu Sains: Jurnal Pendidikan Sains \& Matematika 2 (1). 